\title{
Fungal-induced water repellency in sand
}

\author{
EMMANUEL SALIFU* and GRÁINNE EL MOUNTASSIR †
}

\begin{abstract}
Water infiltration into granular soils and the associated pore water pressure increase and reduction in shear strength can trigger landslides, instability of vertical cuts and failure of retaining walls. Waterrepellent soils can reduce infiltration to maintain soil suction. Recent research has demonstrated the creation of synthetic water-repellent soils using chemical methods. This paper investigates a biological treatment for creating water-repellent sand by way of the growth of the fungus Pleurotus ostreatus. Water repellency was assessed using: $(a)$ the water drop penetration test; $(b)$ the molarity of ethanol drop test; and $(c)$ the modified sessile drop method with contact angle $(\theta)$ determination by way of image analysis. Fungal-induced water repellency was found to be 'extreme' $\left(\theta>110^{\circ}\right)$ up to 4 weeks and 'severe' $\left(\theta>105^{\circ}\right)$ up to 12 weeks, even with no further supply of moisture or nutrients. A water-repellent layer was formed and maintained in saturated conditions, which is difficult to achieve using chemical methods.
\end{abstract}

KEYWORDS: ground improvement; water flow

\section{INTRODUCTION}

Water-repellent soils, defined as having a liquid-solid contact angle, $\theta>90^{\circ}$, can delay, reduce or prevent infiltration, lower evaporation and prevent capillary rise (e.g. Letey et al., 1962; Brandt, 1969; DeBano, 1981; Doerr et al., 2000; Wang et al., 2003; Shokri et al., 2009; Rye \& Smettem, 2017). As such they have been proposed to minimise infiltration into slopes, to divert water away from expansive soils, to improve drainage of sports surfaces and to create barriers for use in landfill caps, or canal/trench liners (Dell'Avanzi et al., 2010; Bardet et al., 2011; Lourenço et al., 2017). Water infiltration into granular soils and the associated pore water pressure increase and reduction in shear strength is a well-known mechanism, which can trigger landslides, instability in vertical cuts and failure of retaining walls (Stanier \& Tarantino, 2013; Scotto di Santolo et al., 2017; Balzano et al., 2019).

Recent research has demonstrated the creation of synthetic water-repellent soils using chemically based agents to coat soil grains, including wax (Bardet et al., 2011, 2014), silane compounds (Bachmann et al., 2000; Bauters et al., 2000; Daniels \& Hourani, 2009; Byun et al., 2012 ; Lourenço et al., 2015; Chan \& Lourenço, 2016; Ng \& Lourenço, 2016; Keatts et al., 2018), polytetrafluorethylene (PTFE) (Dell'Avanzi et al., 2010; Lee et al., 2015) and organic acids (Subedi et al., 2012; González-Peñaloza et al., 2013; Wijewardana et al., 2015). The ability to induce water repellency in soils in situ by way of chemical treatment may be limited by: $(a)$ the hazardous effects of some of the chemicals to humans and the environment - for example, dimethyldichlorosilane (DMDCS) reacts with water to produce hydrogen chloride fumes (Chan \& Lourenço, 2016); (b) the

Manuscript received 15 November 2019; revised manuscript accepted 20 March 2020. Published online ahead of print 6 May 2020.

Discussion on this paper closes on 1 November 2021, for further details see $p$. ii.

* Department of Civil \& Environmental Engineering, University of Strathclyde, Glasgow, UK; Dipartimento di Ingegneria Civile, Edile e Ambientale, Università di Napoli, Federico II, Italy

(Orcid:0000-0002-4058-4173).

$\dagger$ Department of Civil \& Environmental Engineering, University of Strathclyde, Glasgow, UK. conditions required for treatment - for example, wax-coated soils require heating to high temperatures (Bardet et al., 2014); $(c)$ the influence of organic matter; and $(d)$ the influence of residual water content; silanes are sensitive to residual water and organic matter in soils, requiring increased amounts of chemical compounds to be added with increasing water content (Chan \& Lourenço, 2016; Ng \& Lourenço, 2016). Naturally occurring water repellency in soils is typically associated with increased soil erosion, as a result of reduced infiltration and increased surface runoff (e.g. Doerr et al., 2006); similar behaviour has also been observed in chemically induced water-repellent soils (Zheng et al., 2017, 2019).

This paper proposes that water repellency in granular soil could be engineered by biological treatment in situ with fungi in order to reduce water infiltration (e.g. in slopes) and thus maintain soil suction and strength. Filamentous fungi grow by way of the formation of hyphae - multi-cellular tube-like structures - which also serve as distribution channels for the protein compounds they secrete. Most filamentous fungi secrete hydrophobins, which are proteins that have both hydrophilic and hydrophobic ends (amphipathic), enabling the fungi to hydrophobise wettable surfaces and vice versa (Wessels, 1996, 2000; Wösten, 2001). A network of hyphae, known as the mycelium, is created as a filamentous fungus grows. This, along with the exudates, results in the physical enmeshment of soil particles and an overall enhanced resistance to wind or water erosion (Vogelsang et al., 2004; Tisdall et al., 2012; Mardhiah et al., 2016).

The aim of this paper is to assess the level of water repellency that can be induced in sterile sand treated with Pleurotus ostreatus, a non-pathogenic, non-parasitic, saprotrophic, filamentous fungus. Specifically, the objectives are to

(a) assess the degree and persistence of water repellency induced over a 12 week growth period (experiment 1)

(b) investigate the influence of initial degree of saturation (experiment 2)

(c) investigate the influence of disruption of the mycelium network (experiment 3).

\section{MATERIALS AND METHODS \\ Experimental design}

Three experiments were conducted to address the objectives, the details of each are presented in Table 1. 


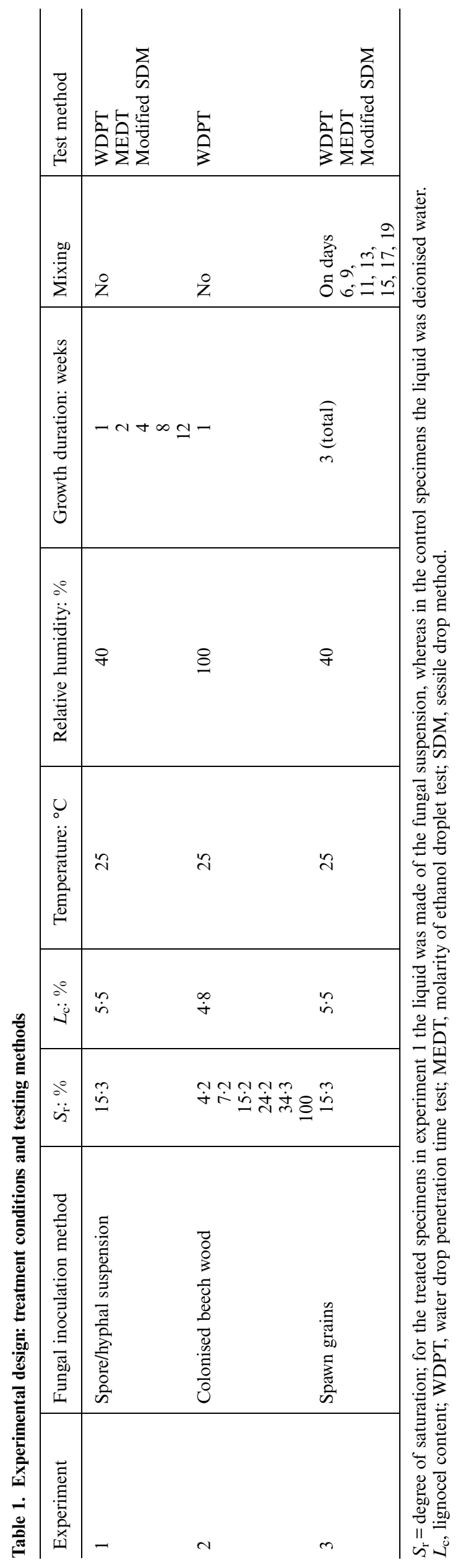

Preparation of specimens

A fine sand, with particle size ranging from 0.075 to $0.425 \mathrm{~mm}\left(C_{\mathrm{u}}=1.7\right)$, was mixed with lignocellulose, natural wood fibres sized $0.51 \mathrm{~mm}$ (J. Rettenmaier \& Söhne $\mathrm{GmbH}$ ). The lignocellulose provided the carbon source for fungal growth, and was sterilised by autoclaving at $121^{\circ} \mathrm{C}$ for $21 \mathrm{~min}$.

In experiment 1, the spore/hyphal suspension of P. ostreatus (strain M 2191) was prepared by mixing $10 \mathrm{~g}$ of spawn (mycelium grown on millet grains) in $100 \mathrm{ml}$ of deionised water and shaking vigorously for $10 \mathrm{~min}$, then placing on a shaker at $150 \mathrm{r} / \mathrm{min}$ for $20 \mathrm{~min}$, followed by another $5 \mathrm{~min}$ of vigorous shaking by hand to facilitate detachment of fungal spores and hyphae from the grains into the water. Using a sieve with $2 \mathrm{~mm}$ mesh size, the grains were removed. The resulting filtrate formed the liquid content of the fungal treated specimens. In the control specimens, water was added in place of the spore/hyphal suspension.

In experiment 2 colonised beech wood inocula were prepared according to the method described in Donnelly \& Boddy (1998). Each specimen was inoculated by placing a cube of beech wood colonised by $P$. ostreatus on the soil surface in the middle of a Petri dish.

In experiment 3 , specimens were treated by placing grains of spawn of $P$. ostreatus directly on to the specimen surface. To determine if fungal-induced soil water repellency persists when the mycelium networks are disrupted (which may occur in the field due to human or animal actions), specimens were thoroughly mixed using a spatula 6 days after inoculation. Water drop penetration time (WDPT) tests were performed on day 6 prior to and immediately after mixing. WDPT tests were carried out again on day 7. Specimens were then mixed every $48 \mathrm{~h}$ and tested on days 12 and 20 .

\section{Assessment of water repellency}

The procedures followed in assessing water repellency for the respective experiments are presented in Table 2. A modified sessile drop method (SDM) was used, as the standard method involves sampling using double-sided adhesive and this was considered too invasive, disturbing the arrangement of the fungal mycelium on the sand grains.

The relationship between the level of water repellency, water penetration time and equivalent contact angles for sands is shown in Table 3.

\section{RESULTS}

Experiment 1: Persistence of water repellency with time

After 1 week of growth, water droplets remained on the surface of fungal treated sand beyond $24 \mathrm{~h}$ and formed contact angles $\sim 118^{\circ}$, whereas for the corresponding untreated control specimen water droplets infiltrated immediately within $\leq 2 \mathrm{~s}$, meaning that contact angles could not be accurately measured. Figs 1(a) and 1(b) show an untreated specimen on day 0 and after 12 weeks of incubation. In contrast Figs 1(c)-1(e) show water droplets on a treated specimen after 12 weeks of fungal growth. Fig. 2 and Table 4 show the evolution of contact angles and WDPT with growth duration. The contact angles and WDPT indicate that the fungal treated specimens are extremely to severely water repellent up to 8 weeks after inoculation and although both reduce with increasing growth duration, after 12 weeks the fungal treated sand remains severely water repellent. Even under these harsh environmental conditions, where no additional moisture or nutrients were supplied to the sterile sand specimens after initial treatment, water repellency persisted for the entire 12 weeks investigated. 
Table 2. Methods and procedures for the assessment of water repellency

\begin{tabular}{|c|c|c|}
\hline Method & Procedure & References \\
\hline $\begin{array}{l}\text { Water drop penetration time } \\
\text { (WDPT) test }\end{array}$ & $\begin{array}{l}\text { Time recorded for a water droplet (vol. } 10 \mu \mathrm{l}) \text { released from a } \\
\text { height of } 5 \mathrm{~mm} \text { above the specimen surface, to infiltrate } \\
\text { the soil. Repeated five times per specimen. }\end{array}$ & Letey (1969), Doerr (1998) \\
\hline $\begin{array}{l}\text { Molarity of ethanol droplet test } \\
\text { (MEDT) }\end{array}$ & $\begin{array}{l}\text { Droplets of ethanol solution (vol. } 50 \mu \mathrm{l}) \text { released from a } \\
\text { height of } 5 \mathrm{~mm} \text { above the specimen surface. Solutions } \\
\text { of ethanol at increasing concentrations from } 0 \text { to } 6 \text { mol/l } \\
\text { (at increments of } 0 \cdot 2 \text { mol/l) were used. Repeated three } \\
\text { times per specimen. The } 90^{\circ} \text { liquid surface tension of the } \\
\text { infiltrating droplet }\left(\gamma_{\left.90^{\circ}\right)} \text { and subsequently the contact }\right. \\
\text { angle }(\theta) \text { were determined using the equations given by } \\
\text { Carrillo et al. }(1999) \text { and Leelamanie } \text { et al. }(2008) \text {. }\end{array}$ & $\begin{array}{l}\text { Doerr (1998), Carrillo et al. (1999), } \\
\text { Roy \& McGill (2002), Leelamanie } \\
\text { et al. (2008), Moody \& } \\
\text { Schlossberg (2010) }\end{array}$ \\
\hline $\begin{array}{l}\text { Modified sessile drop method } \\
\text { (SDM) with contact angle } \\
\text { determination by way of image } \\
\text { analysis }\end{array}$ & $\begin{array}{l}\text { Time lapse images recorded of water droplets (vol. } 10 \mu \mathrm{l} \text { ) } \\
\text { released on to bulk specimen surface at } 1 \mathrm{~s} \text { intervals using } \\
\text { a } 1000 \mathrm{X} \text {-USB-microscope-camera. Three measurements } \\
\text { per specimen. The contact angle was estimated using the } \\
\text { low-bond axisymmetric drop shape analysis (LBADSA) } \\
\text { plug-in in ImageJ software. }\end{array}$ & $\begin{array}{l}\text { Bachmann et al. }(2000,2003) \\
\quad \text { Stalder et al. }(2010)\end{array}$ \\
\hline
\end{tabular}

Table 3. Relationship between WDPT, level of water repellency and equivalent contact angles for sands (after Bisdom et al., 1993; Dekker \& Ritsema, 1994; Doerr et al., 2006; Liu et al., 2012)

\begin{tabular}{l|c|c}
\hline $\begin{array}{l}\text { Level of water } \\
\text { repellency }\end{array}$ & $\begin{array}{c}\text { Water drop } \\
\text { penetration time: s }\end{array}$ & $\begin{array}{c}\text { Equivalent contact } \\
\text { angle } \theta \text { for sands: deg }\end{array}$ \\
\hline $\begin{array}{l}\text { Hydrophilic } \\
\text { Slight }\end{array}$ & $<5$ & 0 \\
Moderate & $6-60$ & $0-80$ \\
Severe & $61-600$ & $80-110$ \\
Extreme & $601-3600$ & $>110$ \\
\hline
\end{tabular}

\section{Experiment 2: Influence of initial degree of saturation $\left(\mathrm{S}_{r}\right)$}

Water repellency was consistently extreme (with WDPT $>3600 \mathrm{~s}$ ) as $S_{\mathrm{r}}$ increased from $4 \cdot 2$ to $15 \cdot 2 \%$ but decreased to 'severe' and 'moderate' levels as $S_{\mathrm{r}}$ increased from $24 \cdot 2$ to $100 \%$ (Fig. 3). It is worth noting that water repellency was not lost, even at saturation (Fig. 3). At saturation the fungal mycelium formed a hydrophobic layer at the water-air interface, rather than growing directly around the sand grains (Fig. 4). It was observed that irrespective of initial $S_{\mathrm{r}}$, $P$. ostreatus induced water repellency wherever fungal mycelium was visible. This is a significant finding, given that for most chemical methods of inducing water repellency (wax, DMDCS, stearic acid), the soils should initially be in a dry state (Leelamanie \& Karube, 2007; Bardet et al., 2014; Chan \& Lourenço, 2016).

\section{Experiment 3: Influence of the disruption of the mycelium network}

For the fungal treated specimens after 6 days of growth, the water droplets did not infiltrate even after $24 \mathrm{~h}$ and formed contact angles of $\sim 110^{\circ}$ (Figs 5(a) and 5(b)). However, immediately after mixing the soil, the WDPT was $<5$ s. After $24 \mathrm{~h}$, slight to moderate water repellency was regained. Thereafter the specimens were mixed every $48 \mathrm{~h}$ (dashed vertical lines in Fig. 5). It is evident that despite regular mixing of the sand specimens water repellency was regained, from slight hydrophobicity (WDPT = 134 s) on day 7 to severe hydrophobicity on day 12 (WDPT $1565 \mathrm{~s}$; contact angle $\sim 100^{\circ}$ ) and finally to extreme hydrophobicity (WDPT $3400 \mathrm{~s}$; contact angle $115^{\circ}$ ) on day 20 .

Although immediately after mixing on day 6, water repellency had been lost, these results suggest that $24 \mathrm{~h}$ is sufficient for the fungal treated specimens to restore some level of hydrophobic behaviour, without any further introduction of fungal inoculation or nutrients. Two mechanisms are suggested for the persistence of water repellency after mycelium disruption. (a) The repeated mixing redistributes the hydrophobins, such that they progressively coat grain surfaces. This may explain why water repellency remains, and is extreme even when there is no obvious mass of fungal mycelium remaining on the sand surface after repeated mixing (Fig. 6). The specimen has transitioned from one with a hydrophobic surface layer to a sand with hydrophobised grains. (b) Filamentous fungi are naturally self-healing, such that if hyphal cells become damaged, septal pores can be plugged using Woronin bodies or septal pore caps, preventing loss of cytoplasmic fluids and ensuring continuous hyphal growth (Jedd \& Pieuchot, 2012).

\section{DISCUSSION}

Fungal treatment has promise in applications which have previously considered the use of chemically hydrophobised soils as fill materials; moreover it has potential to be used to induce water repellency in soils in situ, which is currently only possible with some of the chemical techniques reported in the literature (e.g. organosilanes (Daniels \& Hourani, 2009)). Treatment of granular soils in slopes/hillsides where failures are triggered in response to wetting could be carried out by way of fungal treatment to reduce infiltration, thereby maintaining higher levels of suction and associated strength, without enhancing soil erosion.

Fungal treatment has a number of characteristics which make it attractive for in situ treatment: $(a)$ fungi can grow to massive sizes, a single organism in North America is $\sim 150000 \mathrm{~m}^{2}$ (Smith et al., 1992); (b) fungi can be incredibly long lived, with individuals dated as $\sim 1500$ years old (Smith et al., 1992); (c) fungal treatment would be inexpensive and could be carried out in a similar manner to hydroseeding; $(d)$ water repellency can be induced irrespective of initial saturation; (e) fungi can survive and even thrive in nutrientpoor environments (Sterflinger, 2000; Gorbushina, 2007; Cantrell et al., 2011); and ( $f$ ) fungal hyphae and mycelium networks are self-healing (Müller et al., 1998; Plamann, 2009; Jedd \& Pieuchot, 2012; Tegelaar \& Wösten, 2017).

Although water repellency has been assessed here as a first step using contact angles, it should be noted that intrusion of water into fungal treated soils is also a function of the surface tension, pore size and geometry, all of which may be altered 


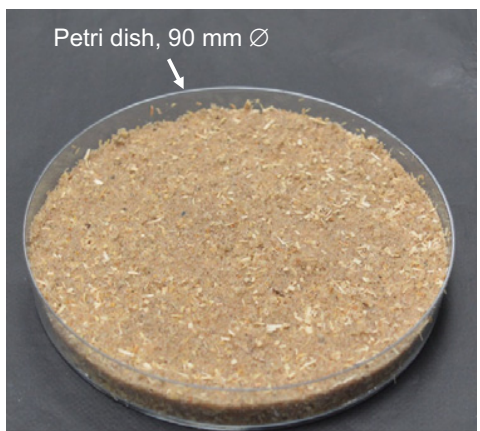

(a)

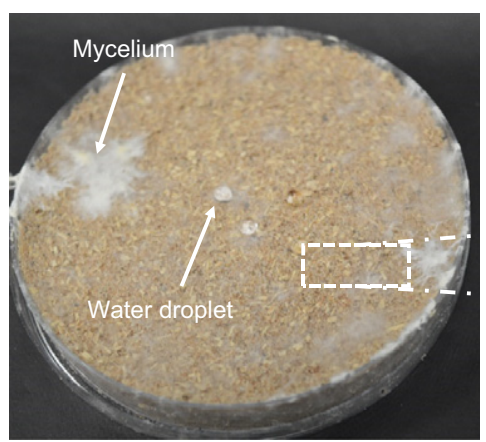

(c)

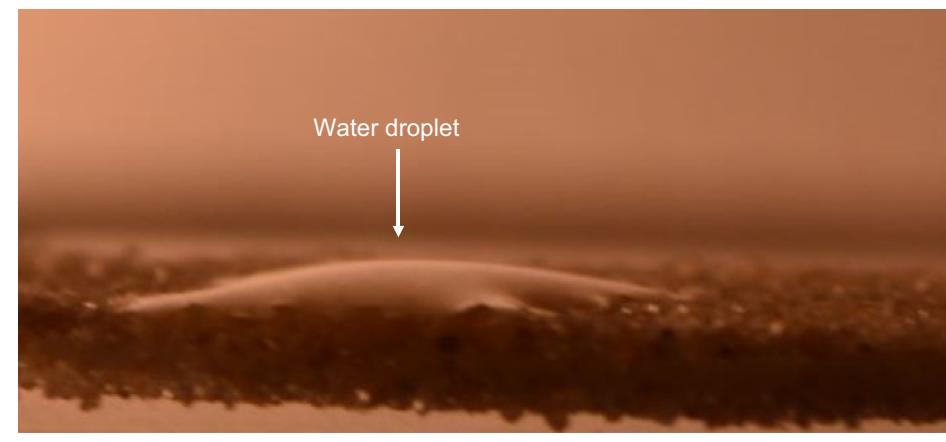

(b)

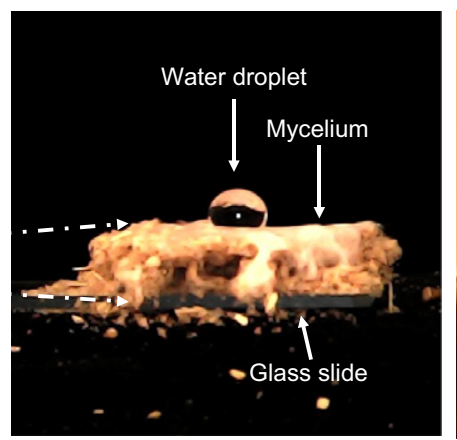

(d)

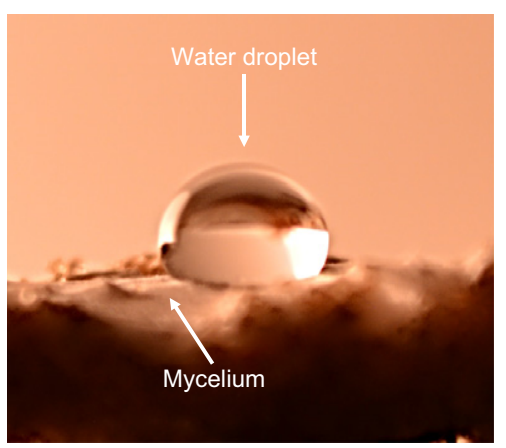

(e)

Fig. 1. Untreated specimens: (a) on day 0 and (b) after 12 weeks' incubation. Water droplets on treated specimens after a growth period of 12 weeks: (c), (d) and (e) images captured from the modified SDM set-up for the treated specimen after a growth period of 12 weeks

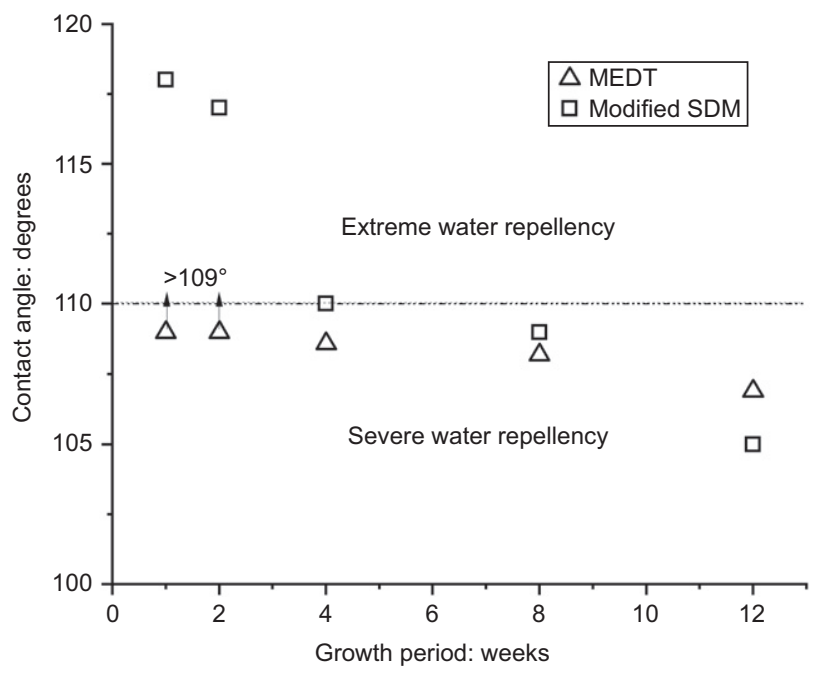

Fig. 2. Evolution of contact angle with growth duration. Levels of water repellency are shown based on classification presented in Table 3

by the presence of fungal biomass, and the water pressure applied (Washburn, 1921). Further research is needed to understand these changes alongside a detailed investigation of the hydraulic behaviour (including determination of the water-entry pressure required for breakthrough, hydraulic conductivity) following fungal treatment in order to understand its potential for reducing infiltration into granular soils. Indeed, for other applications, this should be investigated for a range of soil types, as fungal activity may enhance the formation of clay aggregates, increase clay porosity (Chenu, 1989) and align clay particles along hyphae (Rillig \& Mummey, 2006 ) with the potential for the development of preferential flow paths.

Although some fungal organisms are known to be very long lived in the natural environment with sufficient nutrient
Table 4. Water drop penetration time evolution with growth duration

\begin{tabular}{l|c|l}
\hline $\begin{array}{l}\text { Growth period: } \\
\text { weeks }\end{array}$ & $\begin{array}{c}\text { Water drop penetration } \\
\text { time (WDPT) }\end{array}$ & $\begin{array}{l}\text { Classification of } \\
\text { water repellency }\end{array}$ \\
\hline 1 & $>24 \mathrm{~h}$ & Extreme \\
2 & $>1 \mathrm{~h}$ & Extreme \\
4 & $>1 \mathrm{~h}$ & Extreme \\
8 & $3400 \mathrm{~s}$ & Severe \\
12 & $607 \mathrm{~s}$ & Severe \\
\hline
\end{tabular}

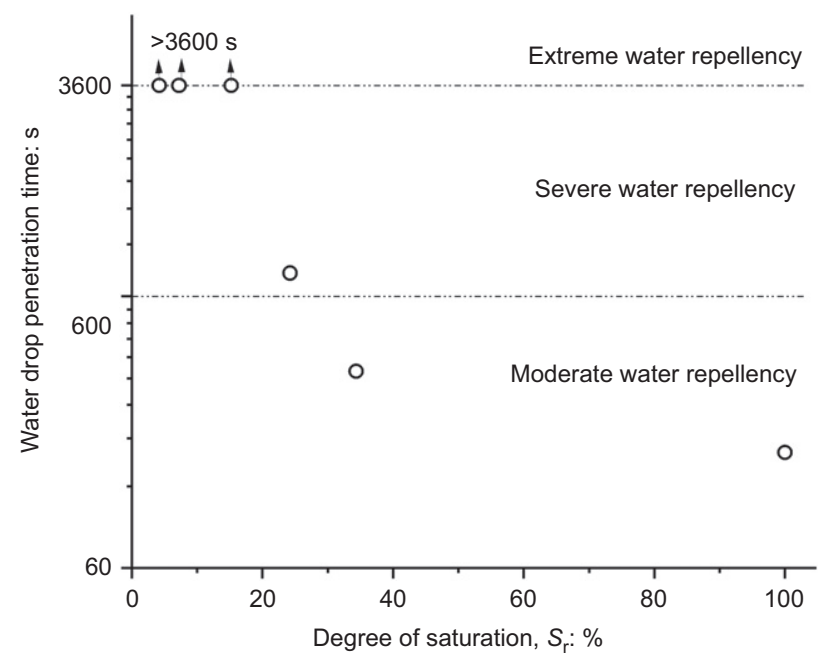

Fig. 3. Influence of initial degree of saturation on water drop penetration time. Levels of water repellency are shown based on classification presented in Table 3

availability (Smith et al., 1992), the survival of $P$. ostreatus in extreme environmental conditions (e.g. wetting-drying cycles) remains to be investigated. Some studies have reported that fungal biochemical exudates (such as glomalin 


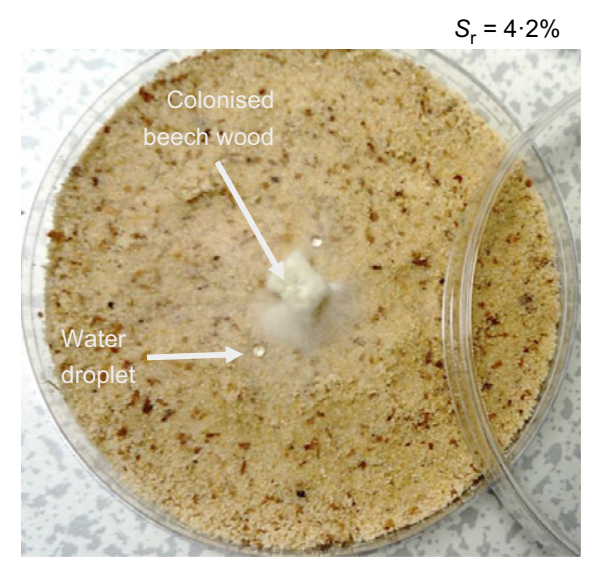

(a)

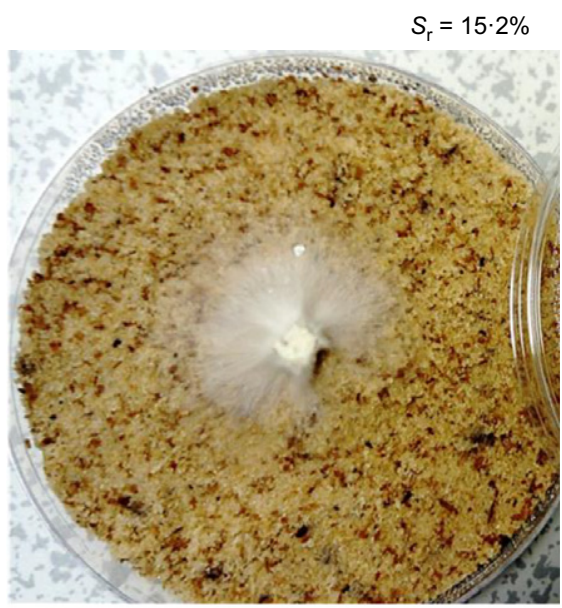

(c)

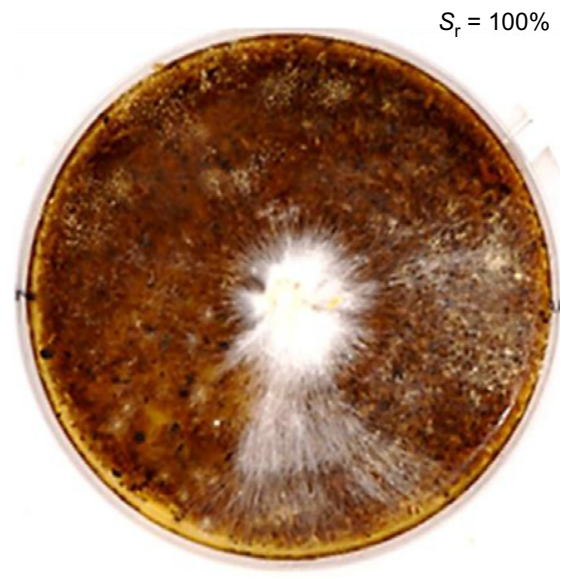

(e)

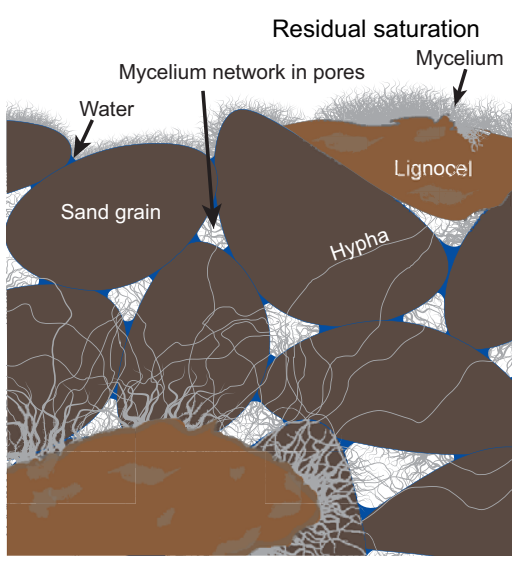

(b)

Partial saturation

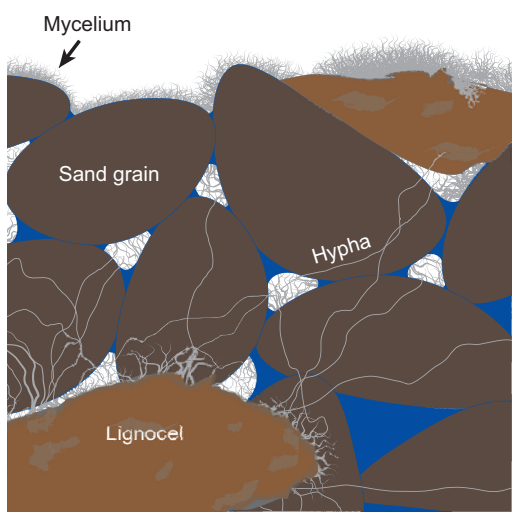

(d)

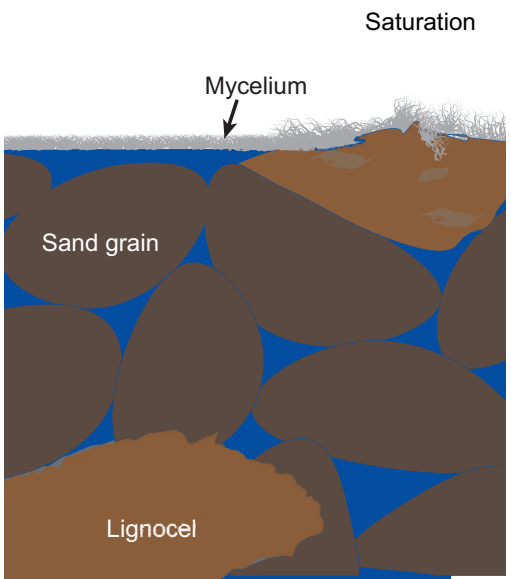

(f)

Fig. 4. Photographs and schematic representations showing formation of hydrophobic layers at different saturation states. At residual saturation (a) and (b) mycelium grows within pore space and on the surface of the specimen. At partial saturation (c) and (d) mycelium grows within reduced pore space and on the surface of the specimen. At saturation (e) and (f) mycelium forms only on the surface of the specimen

produced by arbuscular mycorrhizal fungi) may persist in the soil long after decomposition of fungal hyphae (Rillig \& Mummey, 2006), but it is unclear at present for how long residual water repellency could be sustained.

This study has presented the hydrophobic effects due to the introduction of a single fungal species, $P$. ostreatus. Yet it should be noted that there are 99000 known fungal species (Carris et al., 2012). Indeed P. ostreatus is a saprotrophic fungus, which digests non-living organic matter namely, wood - and as such it would not be suitable for deployment near wooden structures due to the potential for decay. It is anticipated that many other fungal species could also induce similar water-repellent behaviour in soils to that presented herein. The selection of a species should also consider if there is any potential for damage to other infrastructure on site under low nutrient conditions. Furthermore, the success of bioaugmentation strategies (i.e. the introduction of a single species) in situ can be limited by a decline in microbial population after injection due to environmental conditions, but primarily as a result of biotic effects - for example, predation and/or competition by native microbial communities (Van Veen et al., 1997). Biostimulation of native 


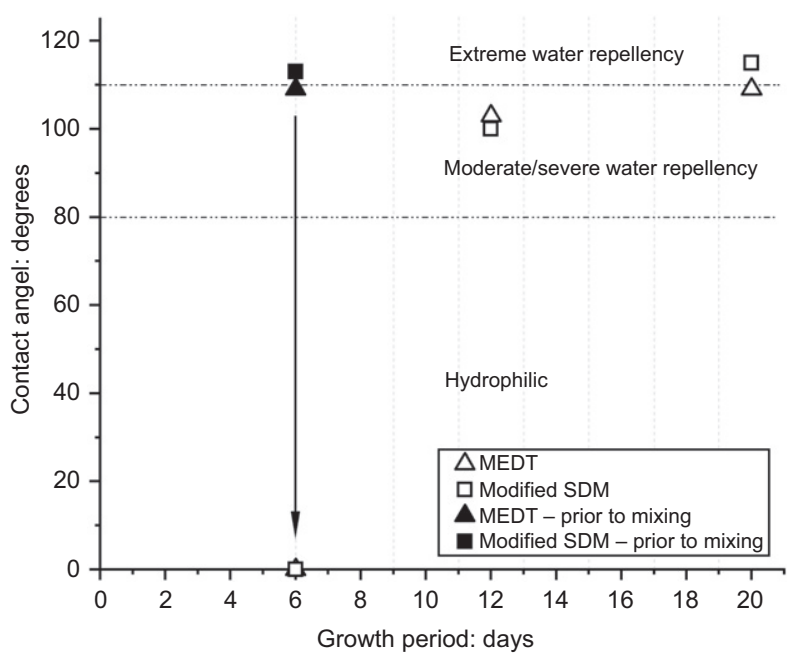

(a)

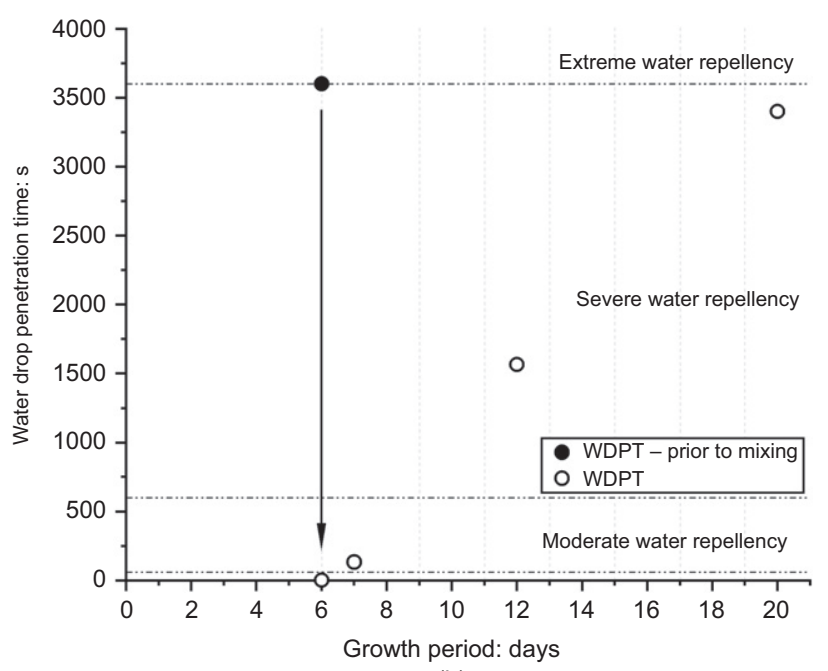

(b)

Fig. 5. Assessment of water repellency for treated soil specimens subjected to mixing every $48 \mathrm{~h}$ to disrupt fungal growth up to 20 days: (a) contact angle and (b) water drop penetration time. The dashed vertical lines indicate days on which specimens were mixed. The arrows show that the initially extreme water repellency exhibited by specimens (black symbols) was completely lost immediately after mixing on the sixth day

microorganisms may be a more promising strategy in the long term.

\section{CONCLUSIONS}

This study proposes for the first time that water-repellent sand could be created for ground engineering applications using fungal treatment. Water repellency was induced in sterile sands by way of the growth of $P$. ostreatus. The findings of this study are listed below.

(a) Fungal-induced water repellency was found to be extreme (contact angles $\geq 110^{\circ}$ ) for up to 4 weeks, and severe for up to 12 weeks (contact angles $\geq 105^{\circ}$ ) in a resource-depleting environment.

(b) Water repellency induced by $P$. ostreatus reduces with increasing initial saturation. However, a hydrophobic layer with moderate water repellency can still be created, even in fully saturated conditions.

(c) Disruption of fungal mycelium networks in sand results in a loss of water repellency, but this was shown to re-establish within $24 \mathrm{~h}$.

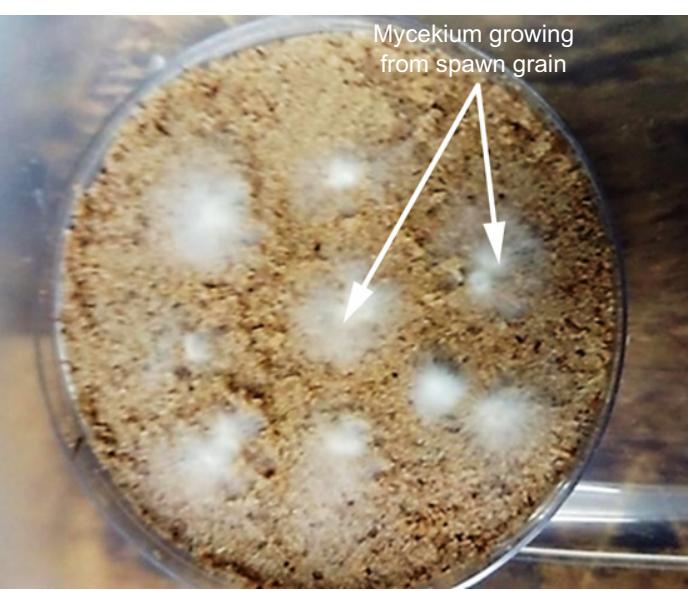

(a)

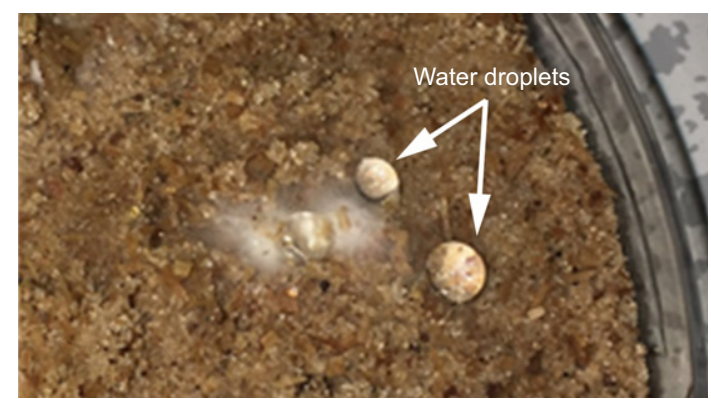

(b)

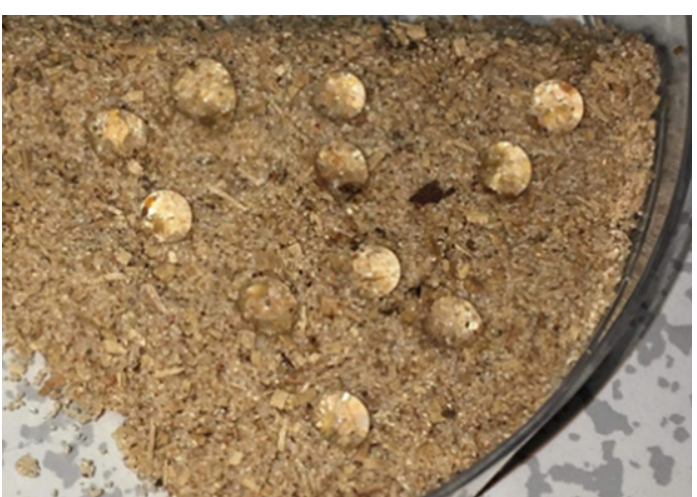

(c)

Fig. 6. Photographs illustrating that mycelium (i.e. fungal hyphae) become less visible with increased mixing: (a) specimen on the sixth day before testing; (b) water droplet on specimen on the sixth day immediately before mixing; (c) several water droplets on specimen with no visible mycelium on the 20th day after being subjected to 48 hourly mixing

\section{ACKNOWLEDGEMENTS}

The authors wish to acknowledge the support of the European Commission by way of the Marie SkłodowskaCurie Innovative Training Networks (ITN-ETN) project TERRE 'Training engineers and researchers to rethink geotechnical engineering for a low carbon future' (H2020MSCA-ITN-2015-675762) and the Engineering and Physical Sciences Research Council (EPSRC) by way of grant EP/N035526/1. The authors would also like to acknowledge the assistance of Dionne Johnson in carrying out some of the tests in experiment 3 .

\section{Data statement}

Data associated with this publication are openly available from the University of Strathclyde KnowledgeBase at https:// doi.org/10.15129/1671ac61-507a-4fc9-a215-370c4178c8c5. 


\section{REFERENCES}

Bachmann, J., Ellies, A. \& Hartge, K. H. (2000). Development and application of a new sessile drop contact angle method to assess soil water repellency. J. Hydrol. 231-232, 66-75, https://doi. org/10.1016/S0022-1694(00)00184-0.

Bachmann, J., Woche, S. K., Goebel, M. O., Kirkham, M. B. \& Horton, R. (2003). Extended methodology for determining wetting properties of porous media. Water Resour. Res. 39, No. 12, article 1353, https://doi.org/10.1029/2003WR002143.

Balzano, B., Tarantino, A. \& Ridley, A. (2019). Preliminary analysis on the impacts of the rhizosphere on occurrence of rainfall-induced shallow landslides. Landslides 16, No. 10, 1885-1901, https://doi.org/10.1007/s10346-019-01197-5.

Bardet, J. P., Jesmani, M. \& Jabbari, N. (2011). Effects of compaction on shear strength of wax-coated sandy soils. Electron. J. Geotech. Engng 16D, 451-461.

Bardet, J. P., Jesmani, M. \& Jabbari, N. (2014). Permeability and compressibility of wax-coated sands. Géotechnique 64, No. 5, 341-350, https://doi.org/10.1680/geot.13.P.118.

Bauters, T. W. J., Steenhuis, T. S., Dicarlo, D., Nieber, J. L., Dekker, L., Ritsema, C. J., Parlange, J. Y. \& Haverkamp, R. (2000). Physics of water repellent soils. J. Hydrol. 231-232, 233-243, https://doi.org/10.1016/S0022-1694(00)00197-9.

Bisdom, E. B. A., Dekker, L. W. \& Schoute, J. F. T. (1993). Water repellency of sieve fractions from sandy soils and relationships with organic material and soil structure. Geoderma 56, No. 1, 105-118, https://doi.org/10.1016/0016-7061(93)90103-R.

Brandt, G. H. (1969). Water movement in hydrophobic soils. In Water-repellent soils: proceedings of the symposium on waterrepellent soils (eds L. F. DeBano and J. Letey), pp. 91-115. Riverside, CA, USA: University of California.

Byun, Y., Tran, M. K.. Yun, T. S., \& Lee, J. (2012). Strength and stiffness characteristics of unsaturated hydrophobic granular media. Geotech. Test. J. 35, No. 1, 1-8, https://doi.org/10. 1520/GTJ103650.

Cantrell, S. A., Dianese, J. C., Fell, J., Gunde-Cimerman, N. \& Zalar, P. (2011). Unusual fungal niches. Mycologia 103, No. 6, 1161-1174, https://doi.org/10.3852/11-108.

Carrillo, M. L., Letey, J. \& Yates, S. R. (1999). Measurement of initial soil-water contact angle of water repellent soils. Soil Sci. Soc. Am. J. 63, No. 3, 433-436.

Carris, L. M., Little, C. R. \& Stiles, C. M. (2012). Introduction to fungi. The Plant Health Instructor, https://doi.org/10.1094/ PHI-I-2012-0426-01. See https://www.apsnet.org/edcenter/ disandpath/fungalasco/intro/Pages/IntroFungi.aspx (accessed 29/04/2020).

Chan, C. S. H. \& Lourenço, S. D. N. (2016). Comparison of three silane compounds to impart water repellency in an industrial sand. Geotech. Lett. 6, No. 4, 263-266, https://doi.org/10.1680/ jgele.16.00097.

Chenu, C. (1989). Influence of a fungal polysaccharide, scleroglucan, on clay microstructures. Soil Biol. Biochem. 21, No. 2, 299-305, https://doi.org/10.1016/0038-0717(89)90108-9.

Daniels, J. L. \& Hourani, M. S. (2009). Soil improvement with organo-silane. In Advances in ground improvement (eds J. Han, G. Zheng, V. R. Schaefer and M. Huang), GSP 188, pp. 217-224, https://doi.org/10.1061/41025(338)23. Reston, VA, USA: American Society of Civil Engineers.

DeBano, L. F. (1981). Water repellent soils: a state-of-the-art, General Technical Report PSW-GTR-46, https://doi.org/10. 2737/PSW-GTR-46. Berkeley, CA, USA: US Department of Agriculture Forest Service Pacific Southwest Forest and Range Experimental Station.

Dekker, L. W. \& Ritsema, C. J. (1994). How water moves in a water repellent sandy soil: 1 . Potential and actual water repellency. Water Resour. Res. 30, No. 9, 2507-2517, https://doi.org/ 10.1029/94WR00749.

Dell'Avanzi, E., Guizelini, A. P., Silva, W. R. \& Nocko, L. M. (2010). Potential use of induced soil-water repellency techniques to improve the performance of landfill's alternative final cover systems. In Unsaturated soils: experimental studies in unsaturated soils and expansive soils (eds O. Buzzi, S. Fityus and D. Sheng), pp. 461-466. London, UK: CRC Press, Taylor and Francis group.

Doerr, S. H. (1998). On standardizing the 'water drop penetration time' and the 'molarity of an ethanol droplet' techniques to classify soil hydrophobicity: a case study using medium textured soils. Earth Surf. Processes Landforms 23, No. 7, 663-668, https://doi.org/10.1002/(SICI)1096-9837(199807) 23:7<663::AID-ESP909>3.0.CO;2-6.

Doerr, S. H., Shakesby, R. A. \& Walsh, R. P. D. (2000). Soil water repellency: its causes, characteristics and hydrogeomorphological significance. Earth Sci. Rev. 51, No. 1, 33-65, https://doi.org/10.1016/S0012-8252(00)00011-8.

Doerr, S. H., Shakesby, R. A., Dekker, L. W. \& Ritsema, C. J. (2006). Occurrence, prediction and hydrological effects of water repellency amongst major soil and land-use types in a humid temperate climate. Eur. J. Soil Sci. 57, No. 5, 741-754, https://doi.org/10.1111/j.1365-2389.2006.00818.x.

Donnelly, D. \& Boddy, L. (1998). Developmental and morphological responses of mycelial systems of Stropharia caerulea and Phanerochaete velutina to soil nutrient enrichment. New Phytol. 138, 519-531, https://doi.org/10.1046/J.1469-8137.1998. 00117.X.

González-Peñaloza, F. A., Zavala, L. M., Jordán, A., Bellinfante, N., Bàrcenas-Moreno, G., Mataix-Solera, J., Granged, A. J. P., Granja-Martins, F. M. \& NetoPaixão, H. M. (2013). Water repellency as conditioned by particle size and drying in hydrophobized sand. Geoderma 209-210, 31-40.

Gorbushina, A. A. (2007). Life on the rocks. Environ. Microbiol. 9, No. 7, 1613-1631, https://doi.org/10.1111/j.1462-2920.2007. 01301.x.

Jedd, G. \& Pieuchot, L. (2012). Multiple modes for gatekeeping at fungal cell-to-cell channels. Mol. Microbiol. 86, No. 6, 1291-1294, https://doi.org/10.1111/mmi.12074.

Keatts, M. I., Daniels, J. L., Langley, W. G., Pando, M. A. \& Ogunro, V. O. (2018). Apparent contact angle and water entry head measurements for organo-silane modified sand and coal fly ash. ASCE J. Geotech. Geoenviron. Engng 144, No. 6, $1-9$.

Lee, C., Yang, H. J., Yun, T. S., Choi, Y. \& Yang, S. (2015). Water-entry pressure and friction angle in an artificially synthesized water-repellent silty soil. Vadose Zone J. 14, No. 4, 1-9, https://doi.org/10.2136/vzj2014.08.0106.

Leelamanie, D. \& Karube, J. (2007). Effects of organic compounds, water content and clay on the water repellency of a model sandy soil. Soil Sci. Plant Nutr. 53, No. 6, 711-719, https://doi.org/10. 1111/j.1747-0765.2007.00199.x.

Leelamanie, D., Karube, J. \& Yoshida, A. (2008). Characterizing water repellency indices: contact angle and water drop penetration time of hydrophobized sand. Soil Sci. Plant Nutr. 54, No. 2, 179-187, https://doi.org/10.1111/j.1747-0765.2007. 00232.x.

Letey, J. (1969). Measurement of contact angle, water drop penetration time, critical surface energy. In Water-repellent soils: proceedings of the symposium on water-repellent soils (eds L. F. DeBano and J. Letey), pp. 43-47. Riverside, CA, USA: University of California.

Letey, J., Osborn, J. \& Pelishek, R. E. (1962). The influence of the water-solid contact angle on water movement in soil. Int. Assoc. Sci. Hydrol. Bull. 7, No. 3, 75-81, https://doi.org/10.1080/ 02626666209493272.

Liu, H., Ju, Z., Bachman, J., Horton, R. \& Ren, T. (2012). Moisture dependent wettability of artificial hydrophobic soils and its relevance for soil water desorption curves. Soil Sci. Soc. Am. J. 76, No. 2, 342-349, https://doi.org/10.2136/sssaj11.0081.

Lourenço, S. D. N., Wang, G. H. \& Kamai, T. (2015). Water repellent soils for slope stability. In Geotechnical engineering for infrastructure and development: XVI European conference on soil mechanics and geotechnical engineering (eds M. G. Winter, D. M. Smith, P. J. L. Eldred and D. G. Toll), pp. 1609-1613, https://doi.org/10.1680/ecsmge.60678. London, UK: ICE Publishing.

Lourenço, S. D. N., Saulick, Y., Zheng, S., Kang, H., Liu, D., Lin, H. \& Yao, T. (2017). Soil wettability in ground engineering: fundamentals, methods, and applications. Acta Geotech. 13, No. 1, 1-14, https://doi.org/10.1007/s11440-017-0570-0.

Mardhiah, U., Caruso, T., Gurnell, A. \& Rillig, M. C. (2016). Arbuscular mycorrhizal fungal hyphae reduce soil erosion by surface water flow in a greenhouse experiment. Appl. Soil Ecol. 99, 137-140, https://doi.org/10.1016/j.apsoil.2015.11.027. 
Moody, D. R. \& Schlossberg, M. J. (2010). Soil water repellency Index prediction using the molarity of ethanol droplet test. Vadose. Zone. J. 9, No. 4, 1046-1051, https://doi.org/10.2136/ vzj2009.0119.

Müller, W. H., Montijn, R. C., Humbel, B. M., van Aelst, A. C., Boon, E. J., van der Krift, T. P. \& Boekhout, T. (1998). Structural differences between two types of basidiomycete septal pore caps. Microbiology 144, No. 7, 1721-1730, https://doi.org/ 10.1099/00221287-144-7-1721.

Ng, S. H. Y. \& Lourenço, S. D. N. (2016). Conditions to induce water repellency in soils with dimethyldichlorosilane. Géotechnique 66, No. 5, 441-444, https://doi.org/10.1680/jgeot.15.T.025.

Plamann, M. (2009). Cytoplasmic streaming in neurospora: disperse the plug too increase the flow? PLoS Genet. 5, No. 6, e1000526, https://doi.org/10.1371/journal.pgen.1000526.

Rillig, M. C. \& Mummey, D. L. (2006). Tansley review. Mycorrhizas and soil structure. New Phytol. 171, 41-53, https://doi.org/10. 1111/j.1469-8137.2006.01750.x.

Roy, J. L. \& McGill, W. B. (2002). Assessing soil water repellency using the molarity of ethanol droplet (MED) test. Soil Sci. 167, No. 2, 83-97.

Rye, C. F. \& Smettem, K. R. J. (2017). The effect of water repellent soil surface layers on preferential flow and bare soil evaporation. Geoderma 289, 142-149, https://doi.org/10.1016/j.geoderma. 2016.11.032.

Scotto di Santolo, A., Evangelista, L. \& Evangelista, A. (2017). Gravity retaining walls in unsaturated pyroclastic materials: observations and numerical modeling. Rivista Italiana di Geotecnica 51, No. 1, 26-42.

Shokri, N., Lehmann, P. \& Or, D. (2009). Characteristics of evaporation from partially wettable porous media. Water Resour. Res. 45, No. 2, 1-12, https://doi.org/10.1029/ 2008WR007185.

Smith, M. L., Bruhn, J. N. \& Anderson, J. B. (1992). The fungus Armillaria bulbosa is among the largest and oldest living organisms. Nature 356, No. 6368, 428-431, https://doi.org/10.1038/ $356428 \mathrm{a} 0$.

Stalder, A. F., Melchior, T., Müller, M., Sage, D., Blu, T. \& Unser, M. (2010). Low-bond axisymmetric drop shape analysis for surface tension and contact angle measurements of sessile drops. Colloids Surf., A 364, No. 1-3, 72-81, https://doi.org/ 10.1016/j.colsurfa.2010.04.040.

Stanier, S. A. \& Tarantino, A. (2013). An approach for predicting the stability of vertical cuts in cohesionless soils above the water table. Engng Geol. 158, 98-108, https://doi.org/10.1016/j.enggeo. 2013.03.012.

Sterflinger, K. (2000). Fungi as geologic agents. Geomicrobiol. J. 17, No. 2, 97-124, https://doi.org/10.1080/01490450050023791.

Subedi, S., Kawamoto, K., Jayarathna, L., Vithanage, M., Moldrup, P., Wollesen de Jonge, L. \& Komatsu, T. (2012).
Characterizing time-dependent contact angles for sands hydrophobized with oleic and stearic acids. Vadose Zone J. 11, No. 1, 53-62, https://doi.org/10.2136/vzj2011.0055.

Tegelaar, M. \& Wösten, H. A. B. (2017). Functional distinction of hyphal compartments. Sci. Rep. 7, No. 1, 6-11, https://doi. org/10.1038/s41598-017-06422-6.

Tisdall, J. M., Nelson, S. E., Wilkinson, K. G., Smith, S. E. \& McKenzie, B. M. (2012). Stabilisation of soil against wind erosion by six saprotrophic fungi. Soil Biol. Biochem. 50, 134-141, https://doi.org/10.1016/j.soilbio.2012.02.035.

Van Veen, J. A., Van Overbeek, L. S. \& Van Elsas, J. D. (1997). Fate and activity of microorganisms introduced into soil. Biotechnol. Mol. Biol. Rev. 61, No. 2, 121-135.

Vogelsang, K. M., Bever, J. D., Griswold, M. \& Schultz, P. A. (2004). The use of mycorrhizal fungi in erosion control applications, contract report. Sacramento, CA, USA: Caltrans (California Department of Transportation). See https://pdfs.semanticscholar.org/3c44/156d03c80e327913c06fac4fa8084d5584d0.pdf? _ga $=2.216907669 .2012585161 .1572648647-240717194$. 1572648647 (accessed 29/04/2020).

Wang, Z., Wu, Q. J., Wu, L., Ritsema, C. J., Dekker, L. W. \& Feyen, J. (2003). Effects of water repellency on infiltration rate and flow instability. In Soil water repellency: occurrence, consequences, and amelioration (eds C. J. Ritsema and L. Dekker), pp. 235-244, https://doi.org/10.1016/B978-0-444-51269-7. 50024-2. Amsterdam, the Netherlands: Elsevier Science.

Washburn, E. W. (1921). The dynamics of capillary flow. Phys. Rev. 17, No. 3, 273-383.

Wessels, J. G. H. (1996). Hydrophobins: proteins that change the nature of the fungal surface. Adv. Microb. Physiol. 38, 1-45, https://doi.org/10.1016/s0065-2911(08)60154-x.

Wessels, J. G. H. (2000). Hydrophobins, unique fungal proteins. Mycologist 14, No. 4, 153-159.

Wijewardana, N. S., Kawamoto, K., Moldrup, P., Komatsu, T., Kurukulasuriya, L. C. \& Priyankara, N. H. (2015). Characterization of water repellency for hydrophobized grains with different geometries and sizes. Environ. Earth Sci. 74, No. 7, 5525-5539, https://doi.org/10.1007/s12665-015-4565-6.

Wösten, H. A. B. (2001). Hydrophobins: multipurpose proteins. Annu. Rev. Microbiol. 55, No. 1, 625-646, https://doi.org/10. 1146/annurev.micro.55.1.625.

Zheng, S., Lourenço, S. D. N., Cleall, P. J., Chui, T. F. M., Ng, A. K. Y. \& Millis, S. W. (2017). Hydrologic behavior of model slopes with synthetic water repellent soils. J. Hydrol. 554, 582-599, https://doi.org/10.1016/j.jhydrol.2017.09.013.

Zheng, S., Lourenço, S. D. N., Cleall, P. J. \& Ng, A. K. Y. (2019). Erodibility of synthetic water repellent granular materials: adapting the ground to weather extremes. Sci. Total Environ. 689, 398-412, https://doi.org/10.1016/j.scitotenv.2019. 06.328 . 